\title{
9. Female factory inspectors and leadership in early twentieth-century Australia
}

\author{
Joy Damousi ${ }^{1}$
}

In her memoirs published in 1921, the British factory inspector Adelaide Anderson recalled what drew her to the 'calling' of inspection. The 'idealizing powers of youth ... embarking on a calling that involved conduct of legal proceedings and much other technical knowledge of an entirely novel kind for women of that day, counted for much', she recalled. There were also the 'authority and powers to enquire into and enforce remedies for wrong conditions, or to persuade sympathetic employers to provide amenities that the law could not enforce', which were other appealing aspects of the role. It was unusual for a woman to assume the position, and the appearance of a female inspector immediately drew surprise and comment. ${ }^{2}$

In the context of the rapidly shifting industrial and urban landscapes of the late nineteenth and early twentieth centuries, the role of the female factory inspector invites an analysis of the concept of 'leadership' within the framework of administrative leadership. Some of the women who occupied these roles viewed their position as an opportunity to radicalise the workplace and bring about drastic social change through their activities, while others believed the task of the female inspector was a more modest and reformist one. A contrast in styles could be seen in the work and careers of three Australian female factory inspectors - Agnes Milne, Margaret Cuthbertson and Annie Duncan-all of whom worked as factory inspectors when the position was in its infancy. All of them expressed a vision for better industrial conditions for women and demonstrated considerable administrative flair in attempting to achieve it. Although Duncan and Cuthbertson did not see themselves as leading workingclass women or as spokeswomen on their behalf - unlike Milne - they were effective in advocating an improvement to their conditions. In doing so, they were raising concerns about the appalling industrial conditions of workingclass women that men within the union movement did so ineffectually in the early decades of the twentieth century. In this regard, however militant or otherwise their application of the law, the female factory inspectors were advocating measures to support women's involvement in waged work, changes

1 The University of Melbourne.

2 Adelaide Mary Anderson, Woman in the Factory: An Administrative Adventure 1893-1921 (London: John Murray, 1921), 1. 
to which the male-dominated union movement was indifferent, or paid only lipservice; some unionists feared the competition of lower-paid women workers. In the absence of male unionists' effective intervention, state-supported female factory inspectors were in a unique position to take a particularly constructive role in improving women's working conditions. ${ }^{3}$

By adopting the perspective of administrative leadership embedded within an organisational structure, this chapter argues that the position of the factory inspector points to how leadership can be understood within a bureaucratic framework. While my focus is on particular factory inspectors, the chief aim is to examine how they administered the Factory Acts as a form of leadership. This approach follows recent literature that considers the interplay of processes within administrative structures, and explores how influence within these structures is exercised. ${ }^{4}$

This chapter also aims to position the meaning of leadership within a specific historical context. While the literature on women and leadership is now voluminous, little of it considers notions of leadership historically, or as a category that changes in meaning over time with respect to how specific historical circumstances shaped, defined and contested that meaning. This is especially the case in relation to women, for whom the leadership literature stresses contemporary strategies of management, diverse models of effective leadership, attempts to elevate women into leadership positions and how women leaders can effectively implement workplace change. ${ }^{5}$ As some historians have noted, leadership defined exclusively by traditional notions of power within hierarchical organisations is not a useful model when considering women's historical role and participation in society. In order to capture the diversity and complexity of women's roles in a range of activities in the past, a historically grounded definition that takes into account the opportunities available to women, the diversity of activities they undertook and a more flexible definition of leadership is more appropriate to understanding the role of women in attempting to bring about social change. Equally, while broader definitions of leadership have emerged in the leadership literature, historians continue to define and understand leadership in more conventional terms, largely in relation

\footnotetext{
3 See Raelene Frances, The Politics of Work: Gender and Labour in Victoria, 1880-1939 (Cambridge: Cambridge University Press, 1993); Patricia Grimshaw, "The "Equals and Comrades of Men"? Tocsin and "the Woman Question"', in Debutante Nation: Feminism Contests the 1890s, eds Susan Magarey, Sue Rowley and Susan Sheridan (Sydney: Allen \& Unwin, 1993), 100-13.

4 See Amanda Sinclair's essay in this volume; Mary Uhl-Bien, Russ Marion and Bill McKelvey, 'Complexity Leadership Theory: Shifting Leadership from the Industrial Age to the Knowledge Era', in Leadership, Gender, and Organisation: Issues in Business Ethics, eds P. H. Werhane and M. Painter-Moralnd (London: Springer, 2011), 128-31.

5 See, for instance, Barbara Kellerman and Deborah L. Rhode, eds, Women and Leadership: The State of Play and Strategies for Change (San Francisco: Wiley, 2007); Jean Lau Chin, Bernice Lott and Janis SanchezHucles, Women and Leadership: Transforming Visions and Diverse Voices (Oxford: Blackwell, 2007); Dayle Smith, Women at Work: Leadership for the Next Century (New Jersey: Prentice Hall, 2000).
} 
to political leaders and leaders of institutions or social movements. These studies capture a vital part of Australia's political history, but women who were not engaged in overtly public acts of leadership are often rendered invisible in such historical accounts. ${ }^{6}$

Framing the history of female factory inspectors in this way offers a further departure point from the historiography of factory inspectors. This work has largely focused on the relationship of female inspectors to the women's movement and cross-class encounters ${ }^{7}$ and to their role in anti-sweating reform. ${ }^{8}$ While these perspectives offer key insights into the way in which the role was undertaken in Britain and New Zealand, the Australian context of female factory inspection provides fertile material for considering the diversity of approaches adopted by different factory inspectors as well as an opportunity to explore the historically specific definition of 'leadership' at the turn of the twentieth century.

I will briefly sketch out what factory inspection involved and then turn to how three pioneer women factory inspectors sought to adopt different approaches to their obligations as leading administrators.

\section{The origins of factory inspection}

Factory inspectors were appointed by State governments between the late nineteenth and early twentieth centuries, often as a response to investigations that exposed the abysmal working conditions and subsistence wages of workers in factories and workshops in cities around Australia. Their role was to inspect these places of work and report on the conditions therein. In many cases inspectors had broad powers and were expected to enforce the various State acts governing factories and working conditions. Given the reports of factory inspectors often formed the basis of investigations into working conditions, especially those of working women, there is scope to explore the role they played in representing working-class experience.

There are three significant shifts in this history that took place during the nineteenth and early twentieth centuries. The first was the early Victorian

\footnotetext{
6 For recent works that look at women in prominent politics, see Deborah Brennan and Louise Chappell, eds, 'No Fit Place for Women?' Women in NSW Politics, 1856-2006 (Sydney: UNSW Press, 2006); Madeline Grey, Challenging Women: Towards Equality in the Parliament of Victoria (Melbourne: Australian Scholarly Publishing, 2009); Marian Sawer and Gail Radford, Making Women Count: A History of the Women's Electoral Lobby in Australia (Sydney: UNSW Press, 2009).

7 Ruth Livesey, 'The Politics of Work: Feminism, Professionalisation and Women Inspectors of Factories and Workshops', Women's History Review 13(2) (2004): 233-62.

8 Barbara Harrison and Melanie Nolan, 'Reflections in Colonial Glass? Women Factory Inspectors in Britain and New Zealand 1893-1921', Women's History Review 13(2) (2004): 263-88.
} 
legislation in Britain that was established during the 1830s to 1860 s and that included inspectorates of factories, prisons, schools, mines and railways. Arising out of a need for social reform to address the problems of industrialisation and urbanisation, this legislation established a mechanism whereby inspectors could intervene in certain activities to ensure a range of requirements was being met. ${ }^{9}$

The second aspect of inspection - that of factory legislation within Australiawas established about 50 years later. During the 1880s and 1890s, pressure was exerted from predominately the Protestant churches and the emerging labour movement to appoint factory inspectors to allow them to enter premises and provide a reporting mechanism. ${ }^{10}$ In both Britain and Australia these legislative reforms were designed to protect women and children from the horrors of industrial exploitation.

Finally, from 1905, the federal system of arbitration that was established in Australia ensured that not only women and children were protected, but also all workers. In South Australia, the Industrial Court retained powers of enforcement for inspectors and was responsible for administering laws relating to industrial issues. ${ }^{11}$ Broad powers of inspection remained a central aspect of the court's jurisdiction as inspectors could 'enter any place, or premises ... wherein ... any industry is carried on ... and inspect and view any work, material, machinery, article, matter, or thing whatsoever ... and interrogate any person ... in respect of $\ldots$ any matter or thing of which the Court has cognisance' ${ }^{12}$

The trend of appointing public female factory inspectors emerged at a remarkable time.

First, at the turn of the twentieth century, factory inspection was part of the growth of state bureaucracy and public administration. As Hacking has argued, when new kinds of people came to be counted during the nineteenth century, factory inspectorates in England and Wales 'created ... the official form of the class structure of industrial societies'. ${ }^{13}$ Counting created new ways for 'people to be'. It was not the case that people

spontaneously come to fit their categories. When factory inspectors in England and Wales went to the mills, they found ... people ... loosely

9 Gerald Rhodes, Inspectorates in British Government: Law Enforcement and Standards of Efficiency (Sydney: Allen \& Unwin, 1981), 1-3; Arthur J. Taylor, Laissez-Faire and State Intervention in Nineteenth-Century Britain (London: Macmillan, 1972), 56.

10 Wilfrid Prest, Kerrie Round and Carol Fort, eds, The Wakefield Companion to South Australian History (Adelaide: Wakefield Press, 2001), 526-7.

11 George Anderson, Fixation of Wages in Australia (Melbourne: Macmillan/Melbourne University Press, 1929), 98-9.

12 Ibid., 100.

13 Ian Hacking, 'How Should We Do the History of Statistics?', in The Foucault Effect, eds G. Burchett, C. Gordon and P. Miller (Chicago: Chicago University Press, 1991), 183. 
sorted according to tasks and wages. But when they had finished their reports, mill-hands had precise ways in which to work, and the owner has a clear set of concepts about how to employ workers according to the ways in which he was obliged to classify them. ${ }^{14}$

Second, in the period between 1890 and 1914, women's place in the industrial world underwent a dramatic shift. As manufacturing increased so too did women's place within it. During this time, the opportunities for women in the paid workforce had expanded considerably. In 1913, together with Henrietta McGowan, Cuthbertson published a woman's guide to employment opportunities and working conditions. In Woman's Work, the authors aimed to 'set before the prospective worker the ways and means by which she can earn an honest livelihood, together with some idea of remuneration she may expect to receive as a return for her investment of time, study, work and money'. ${ }^{15}$ The growth of the factory system in the 1880s and 1890s saw increasing numbers of women enter into the system, especially single women. Low wages, long hours and poor working conditions characterised labour in these factories. ${ }^{16}$ 'Sweating' became an increasing problem in these years, and inspectors were particularly vigilant in attempting to eradicate it. Women's entry into the factory system increased dramatically during the federation period, as the belief that only a woman could attend to the needs of female workers gained currency. ${ }^{17}$ The increased incidence of sweating further strengthened the case to specifically employ a female inspector. ${ }^{18}$

Third, the role of female factory inspector offered an opportunity for women to develop a career in a new profession that was evolving. Prior to this, women had been active in 'inspecting' in other ways. Inspection by women dates back to the early part of the nineteenth century in Britain when upper-class and middleclass female reformers 'inspected' the workhouses of the poor, and assisted them with charity, philanthropy and 'rescue work' ${ }^{19}$ Social reformers such as Henry Mayhew and others began the scientific approach to such inspection through their reports and in documenting their findings. ${ }^{20}$ Philanthropy and charity amongst middle-class women were mirrored in Australia and were particularly

\footnotetext{
14 Ian Hacking, 'Making Up People', in Reconstructing Individualism: Autonomy, Individuality, and the Self in Western Thought, eds T. C. Heller, M. Sosna and D. E. Wellbery (Stanford: Stanford University Press, 1986), 223.

15 Henrietta C. McGowan and Margaret Cuthbertson, Woman's Work (Melbourne: Thomas C. Lothian, 1913).

16 Frances, The Politics of Work, 17-20.

17 Harrison Ord, 'Chief Inspector of Factories, to Under Secretary', 24 January 1894, VPRS 3992, Unit 787, Item X 94/5122, Public Records Office, Melbourne.

18 Victorian Government Gazette, 3rd Supplement (13) (1920), 107.

19 Olive Banks, Faces of Feminism: A Study of Feminism as a Social Movement (Oxford: Martin Robertson, 1981-82), 15-19; Barbara Caine, Victorian Feminists (Oxford: Oxford University Press, 1992-93), 105-8. 20 Judith R. Walkowitz, City of Dreadful Delight: Narratives of Sexual Danger in Late-Victorian London (London: Virago, 1992), 19.
} 
evident from the mid nineteenth century. Ladies' benevolent societies attempted to assist the poor, particularly by visiting districts. ${ }^{21}$ 'Inspecting' was deemed to be an appropriate form of political and public activity for middle-class female reformers involved in charity work during the nineteenth century. 'Lady supervisors' assumed considerable power in their supervisorial role, and the reformers perceived of their role as akin to professionals such as medical officers and official inspectors. ${ }^{22}$ The systematic inspection of prisons was a procedure that was actively promoted by female reformers such as Elizabeth Fry. ${ }^{23}$ Factory 'inspecting' derived from this tradition, for whilst it signified an important entree of women into the industrial field, it did so in terms similar to that of the premise of earlier female 'inspectors': that they would bring a feminine quality to a social problem concerning women. There developed a close relationship between factory inspection and philanthropy. The professionalisation of the practice of inspection was part of the growth of government during the nineteenth century. It came into being to regulate the increasing numbers of people in the factories, or enterprises, which had expanded. While its origins date back to the eighteenth century, it was not until the mid to late nineteenth century that it was implemented systematically. ${ }^{24}$

In occupying these positions, female factory inspectors were unusual given the paucity of women in public positions of responsibility and embarking on a career within the embryonic structure of public administration. Margaret Cuthbertson, whose background was in government bureaucracy, saw her role as a social reformer. She brought a feminist sensibility to it, coming from a background of agitating for women's reforms. Agnes Milne used the information-gathering exercise and observation techniques to actively and overtly agitate for social reforms. She took the additional step of interpreting workers' experiences and so exposed herself to accusations of bias, inadvertently entering into what became a battlefield of interpretation between opponents of sweating and those who did not believe it existed. Annie Duncan was neither a proclaimed labour activist nor a feminist; she prided herself on what she saw as a professional undertaking her duties as an inspector, which did not involve adopting an overt political position. But while she did not declare a commitment to an ideological label, Duncan nevertheless was a staunch advocate of change to women's working conditions. Within the administrative structures in which they operated, each of these women was part of a process that aimed to better the conditions for women workers through their regular visits to factories and the reports and

\footnotetext{
21 Penny Russell, 'A Wish of Distinction': Colonial Gentility and Femininity (Melbourne: Melbourne University Press, 1994), 192.

22 Jane Finnis, 'Louisa Twining and the Workhouse Visiting Society' (MA thesis, Department of History, University of Melbourne, 1995), 39-40.

23 See Elizabeth Gurney Fry, Observations on the Visiting, Superintendence, and Government of Female Prisoners (London: 1827).

24 Rhodes, Inspectorates in British Government, 2.
} 
recommendations they documented. Leadership was demonstrated, I argue, through administering the Factory Acts in ways that aimed to improve women's working conditions and highlight areas where improvement was necessary. I will now turn to explore how Cuthbertson, Milne and Duncan achieved this within the administrative structures in which they worked.

Margaret Cuthbertson was appointed as female factory inspector in 1894- the first woman to be appointed to the position in Australia. Cuthbertson was born in 1864. She had worked in the factory system before entering the Victorian Public Service in July 1888 as a telephone switchboard attendant in the postmaster's general department. She joined the public service at the age of twenty-four, earning a salary of $£ 66$ per annum. ${ }^{25}$ With the introduction of the Factories and Shops Act in 1885 and its application a year later, factory inspectors were appointed for the first time. ${ }^{26}$ Victoria was the first to appoint a female inspector. Other States soon followed, when Augusta Zadow was appointed in South Australia in 1895, and Annie Duncan in New South Wales in 1897. ${ }^{27}$

\section{Defining the work in Victoria}

Cuthbertson brought the organisational skills she had acquired as an active feminist to her job as factory inspector. Cuthbertson's experience in the public service led to a long association with the Victorian Women's Public Servants' Association. Cuthbertson had a longstanding commitment to feminist issues. As a member of the executive of the National Council of Women (NCW), she was active in various subcommittees. The work Cuthbertson undertook on many of these subcommittees involved a form of 'inspection'. One such subcommittee lobbied for the appointment of police 'matrons' in city and suburban lockups. ${ }^{28}$

The report of the subcommittee to appoint female police recommended that the conditions at the lockups be improved, and that bail be refused for prostitutes to keep them off the streets from 7 am to $7 \mathrm{pm} .{ }^{29}$ The need to 'protect' women echoes Cuthbertson's other occupation - that of the protection of women in industry. ${ }^{30}$ 'Inspecting' thus became a central role of the organisation and of Cuthbertson's

\footnotetext{
25 'Report of the Chief Inspector of Factories, Work-Rooms and Shops' [hereinafter CIF], Victorian Parliamentary Papers [hereinafter VPP], 3rd Supplement (17) (1894), 105.

26 Raelene Frances, 'Ord, Harrison (1862-1910)', Australian Dictionary of Biography. Volume 11 (Canberra: National Centre of Biography, The Australian National University, 1988), 90.

27 Christine Finnimore, A Woman of Difference: Augusta Zadow and the 1894 Factories Act (Adelaide: Workcover, 1995), 19; Kay Daniels, 'Duncan, Annie Jane (1858-1943)', Australian Dictionary of Biography. Volume 8 (Canberra: National Centre of Biography, The Australian National University, 1981), 366.

28 Woman's Sphere, 10 May 1903: 301.

29 Ada Norris, Champions of the Impossible: A History of the National Council of Women of Victoria 19021977 (Melbourne: The Hawthorn Press, 1978), 12.

30 See ibid., 301-3.
} 
activities. As well as practising it themselves, they advocated the appointment of more inspectors in various areas. In 1904, the NCW argued for the need for the appointment of women inspectors to monitor child welfare, and two years later, supported the Infant Life Protection Act to maximise protection. ${ }^{31}$ The NCW agitated for the appointment of inspectors. In 1909, it was reported that a 'deputation waited on the Chief Secretary to ask that, when new inspectors are appointed to visit boarded-out children, they shall be trained nurses, and especially qualified'. ${ }^{32}$ In regards to education, a letter was sent in 1913 'asking for the appointment of women inspectors in that department' ${ }^{33}$

Cuthbertson's approach was gradual and pragmatic, working within the administrative process. Her aim was social change, but she endeavoured to implement it within the confines of her position. That is not to say that she was not committed to reform on a variety of issues. Cuthbertson protected the rights of women workers and attempted to defend their conditions. The situation of women being retrenched once they reached a certain age was an injustice she highlighted in her reports.

If a girl knows that her wages depend on gaining experience, adaptability and expertness at her trade she will endeavour to acquire them ... but if she knows that when she attains a certain age she must go because her wages must be increased-Well! why should she get old before there is any absolute necessity to do so ${ }^{34}$

That women were being paid according to age, rather than experience, was problematic. ${ }^{35}$

Low wages was another major concern. Dressmakers came in for particular scrutiny. 'Employers are always complaining of the dearth of good workers', Cuthbertson reported, 'but the low wages paid should be sufficient reason to deter any girl who required to earn her living from going into it' ${ }^{36}$ Many employers she found complied with the regulations, 'but there are others who take the fullest advantage possible of the fact that they are not protected by the Act to work them long hours, and refuse to give them a half-holiday' ${ }^{37}$

Cuthbertson saw the benefit of work, when it came to training character, and she was at times sanctimonious when judging her charges.

\footnotetext{
31 Helen E. Gillan, A Brief History of the National Council of Women of Victoria, 1900-1945 (Melbourne: NCW, 1944), 13-14.

32 Ibid., 16.

33 Ibid., 19.

34 CIF, year ended 31 December 1901, VPP 2 (1902), 22.

35 CIF, year ended 31 December 1909, VPP 2 (1910), 14.

36 CIF, year ended 31 December 1903, VPP 2 (1904), 16.

37 CIF, year ended 31 December 1904, VPP 3 (1905), 42.
} 
In the absence of home training and discipline which, unfortunately, so many girls are entirely without, the uniform hours, restraint under which they are placed, regularity of work, and association with older steadier girls, have a decidedly improving effect upon young girls coming into factories, and tend to the formation of a character at once self-restrained and industrious. ${ }^{38}$

She was also critical of other girls, and expressed her frustration with them. Dressmakers, she claimed, 'had neither ambition nor incentive to improve they have been made to understand that as the rate of pay prescribed is progressive with years of service at the trade, they must progress accordingly and make themselves worth the money if they are to be retained'. ${ }^{39}$ The argument that women were replacing men was a constant cry during this time, and Cuthbertson is at pains to impress that this is not the case. After commenting on the increase of women in the various trades under the Acts' in 1906, she emphasised that it 'has been contended that because of the greater increase of women and girls in registered factories, they are taking the place of men, but I do not think these figures bear out this statement' ${ }^{40}$ For Cuthbertson, leadership entailed administering the Factory Acts in ways that aimed to bring about effective and significant social change.

\section{A radical agenda}

Agnes Milne agreed with this objective but her style was a very different one, which reflected an alternative way of bringing about change. Milne redefined the parameters of factory inspection by infusing the role with a radical agenda. Milne politicised the position of factory inspection by acting as a trade union advocate and radical social reformer in her capacity as inspector. She did this through her individual inspector's reports, which could be highly influential in provoking debate and awareness of industrial issues. Milne attempted to exert considerable individual power in the way she represented the conditions of the working classes, and used the information she gathered through her work to promote radical causes. By repeatedly raising the problem of sweating in her reports and in strenuously arguing for this working experience to be fully documented, Milne used her position to advance the rights of the woman worker. Milne was an inspector turned working-class advocate, who used the opportunities available to her within an administrative structure to attempt to directly influence social change.

38 CIF, year ended 31 December 1895, VPP 2 (1896), 7.

39 CIF, year ended 31 December 1905, VPP 2 (1906), 19.

40 CIF, year ended 31 December 1906, VPP 2 (1907), 53. 
Agnes Milne was appointed female factory inspector on 22 July 1896. During the 1890s, sweating became a central concern for feminist and labour activists throughout Australia. It involved usually female labourers undertaking work in their own homes; thus employers saved on overheads and did not have to comply with State regulations governing wages and conditions. The prevalence of sweating provided the motivation for legislation to regulate the labour market. ${ }^{41}$

In a series of articles written in 1899 and published in the Journal of Agriculture and Industry, Milne called for the end of sweating through regulation and the Factory Acts and for work to be performed in factories rather than workshops and homes where they could not be regulated. It was through 'judicious legislation' that she believed 'the toiling masses, both male and female', would be emancipated. ${ }^{42}$ Milne ensured that employers conformed to the conditions laid out in the Factory Acts. Her reports indicate a meticulous and scrupulous approach to ensuring that employers conformed to government regulations of 'hours of work, cleanliness, sanitary facilities, ventilation and light in workshops and factories' ${ }^{43}$ In addition, however, she also agitated against, publicised and politicised the cause of sweating. Taking such an overt political and at times militant stance was unusual for a factory inspector at this time. Unlike Cuthbertson, Milne came through working-class ranks and radical politics. She used her position to promote alternative political programs and workers' rights in ways Cuthbertson would have deemed inappropriate.

Milne had no interest in providing a female sensibility to the inspector's job -in fact, she at times accused women workers of indifference and of being complicit in their own oppression. How did she view her position from a so-called 'woman's standpoint'? The real enemies of women workers were the women themselves, she argued.

So long as there are women (married or unmarried) eager and able to take work to their homes, and do it in the intervals of another business, domestic service, or home duties, the true workers will never disentangle themselves from the vicious circle in which low wages tend to bad work, and bad work compels low wages. ${ }^{44}$

41 Stuart Macintyre, Winners and Losers: The Pursuit of Social Justice in Australian History (Sydney: Allen \& Unwin, 1985), 43.

42 Agnes Milne, 'Woman's Work and Wages', Journal of Agriculture and Industry (October 1899): 343.

43 Helen Jones, In Her Own Name: A History of Women in South Australia from 1836 (Adelaide: Wakefield Press, 1986), 71.

44 Agnes Milne, 'Working of the Factory Act', Journal of Agriculture and Industry ii(4) (November 1898): 387. 
She was disappointed with the indifference of the workers she was protecting: 'I am of [the] opinion that it is in a great measure the fault of the workers themselves, who clamor for cheap bargains, not caring how little their fellow workers get for their labour.' ${ }^{45}$

What Milne brought to inspection as an activist in an official position with labour sympathies marked her out from her middle-class counterparts. This was most apparent in the way in which the category of 'outdoor worker' was especially discussed through Milne's reports. She did not invent the category, but her discussion of it within her inspection reports provided the framework from which she argued for reform. The various activities she identified to be within this category and her views of this assumed a form of representation that, as we shall see, offended others. What were represented as 'facts' and 'interpretation' became blurred in Milne's reports. Although inspection was meant to be a subjective activity of reportage, she used it to construct knowledge in a particular way about health and safety and working conditions, which promoted her cause. As Gerald Rhodes observes, inspection in the late nineteenth century involved 'persuasion rather than prosecution, and ... prevention of breaches of the law rather than their detection'. But Milne saw it as her role not only to scrutinise and assess working conditions and to 'promote the underlying purposes of the legislation', ${ }^{46}$ but also to 'emancipate' the workers.

Milne's crusading zeal to extend the parameters of her inspection reflected her belief that the aim of her work was to have 'all wrongs righted, as far as it is in the power of inspectors to do so'. Inevitably there was growing disquiet that Milne was taking matters into her own hands and conducting inspection business beyond her position. ${ }^{47}$

Milne interpreted her administrative role in terms that attempted to push the boundaries of her position as factory inspector. She endeavoured to administer the Factory Acts in ways that demonstrated a forceful and highly politicised process of leadership. In this regard, her style of operating within her position was in dramatic contrast with that of Annie Duncan, who eschewed political ideology and defined her role in striking and contrasting terms.

\section{New female professionalism}

Annie Duncan came from a background that did not overtly include any desire to serve other causes. For her, it was through her professional identity that she sought to offer a form of 'leadership': a 'pioneer career woman'. It was within

45 'Reports of Inspectors of Factories', Proceedings of the Parliament South Australia 2(i)(54) (1897).

46 Rhodes, Inspectorates in British Government, 64-5.

47 'CIF to the Minister of Industry', 7 January 1897, vol. 1, State Records of South Australia, Adelaide. 
this identity, and in promoting the case of how a single, professional women could bring about social change within an administrative structure, that we could see evidence of a factory inspector administering and monitoring the law within the rules and regulations of the position of factory inspector in professional, rather than necessarily overtly political, terms.

Born in 1858 in Port Adelaide, Duncan inherited a small amount of money from her physician father, who died in 1878. The depression of the 1890s had an impact on her fortunes, and she travelled to London, where she met Lucy Deane, one of the first factory inspectors. There she discovered a network of kindred spirits and connected with the leading factory reformers of the day: Rose Squire, Adelaide Anderson and Beatrice and Sidney Webb. She undertook courses with the National Health Society and the Sanitary Institute. In April 1894, she passed the examination for inspector of nuisances and was appointed to the South Kensington district. Her appointment was not renewed and she then returned to Australia.

Duncan was appointed factory inspector in February 1897 in the labour and industry branch of the NSW Department of Public Instruction under the Factories and Shops Act of 1896. In 1912, she was promoted to inspector, a position she occupied until she retired in 1918.

Her background was not in the labour or women's movements, but sprang instead from a Christian conviction for social justice. A committed Anglican, Duncan was a member of the Women's Auxiliary of the Australian Board of Missions and the Girls' Friendly Society. She was a founder of the Business and Professional Women's Club of Sydney and a member of the Women's Club. After travelling in Australia and overseas during the 1920s, she lived in Adelaide in 1930, where she joined several societies and clubs: the Adelaide Music Salon, the Alliance Française, the Victoria League and the Lyceum Club. Duncan died in $1943 .{ }^{48}$

Duncan's leadership as a factory inspector encompassed the values of fairness, equity and transparency, rather than radical upheaval, but she could be firm and assertive in her application of the industrial laws she was expected to administer and apply to a range of issues and circumstances. The examples below demonstrate a form of leadership that embraced advocating social change within the bureaucracy.

The issue of pay for both male and female workers alerted the need for reform:

Is it not clearly wrong that any girl, or any growing boy, however strong, can legally be called upon to work such excessive hours ... Payment 
of overtime is very frequently held over, in some instances for weeks, and in the majority of cases no allowance either by way of advance or addition is made for tea money. This is rather hard on girls and boys drawing low wages, who have little or no money in their pockets to meet emergencies. ${ }^{49}$

Duncan staunchly opposed the view that women were taking men's jobs and argued that the factory system had in fact created a system of deskilling that meant women were often more adept at factory tasks. As long as they were paid less than men, they would be favoured by employers. Women were also entitled to earn a living respectfully, and not rely on men or the degradation of the factory system. 'I trust that the day will come', she wrote in The Public Service Journal in 1904, 'when the women who do not marry will still be able to support themselves with dignity and success, but in ways better suited to their womanly powers and constitution' ${ }^{50}$

Forming a constant theme in her reports were the dirty, unhygienic and overcrowded working conditions in Sydney's factories. In 1902, Duncan observed how one employer did not recognise the danger of heat in the bakehouse, where women were working directly above the ovens, which made the areas very hot and dangerous. This 'abnormal heat', she observed, should be regarded as 'unsuitable for young growing girls' ${ }^{51}$ Working conditions that Duncan identified were in need of urgent attention included the close proximity of stables to shops and workrooms; that pure and cold drinking water be made available for drinking purposes; and that adequate wash basins be installed. These conditions, Duncan asserted, could be addressed through 'common sense' on the part of the employers and 'discipline' on that of the employees. In the case of the latter, the issue of washbasins in otherwise 'well-ordered factories' was that workers waste time at the basins and that it presents an issue of hygiene. ${ }^{52}$

Furthermore, Duncan addressed the issue of seating arrangements for workers, especially for shop assistants. There was resistance to this, as in 'some cases seats have been put in and then removed when it was supposed that the vigilance of the inspector was relaxing'.$^{53}$ On this issue, she argued that employers were resistant and so pointed to the need for the inspector to have a wider role:

[I]f this provision is to be effectively enforced, that the sections dealing with the matter should be so amended as to give the visiting inspectors,

49 Ibid., 11.

50 Annie Duncan, 'Woman's Place in the Industrial World', The Public Service Journal 10 (November 1904).

51 'Report on the Working of the Factories and Shops Act', NSW Votes and Proceedings 3 (1903), 12.

52 Ibid.

53 Ibid., 13. 
and not the employer or employee the right to determine what form of seat shall be considered satisfactory, and what position such seat shall occupy, so as to be really available for the use of the shop assistants.

Duncan believed that whatever the apparent statements of the employers, there was an expectation that shop assistants would stand the entire time. She undertook her own investigations into this matter:

In a shop in which seats are provided, I heard girls complain of the fatigue to which their tired faces gave testimony, and when, my identity being unknown, I asked them why they did not sit down for a few minutes if they had seats, they laughed at the idea of supposing that they would thus venture to bring down upon themselves the remark of the powers that be..$^{54}$

Duncan's reports are a detailed chronicle of social change in the workplace and especially in manufacturing. In 1904, she argued that major shifts in manufacturing were in fact in the introduction of technologies: 'Much has lately been said on the supposed displacement of men by women, but I venture to think that no such generalization should hastily be made, and that the statistical returns and the experience of this Department do not so far bear out this theory.'

This was because men and women mainly undertook separate tasks. In the tailoring trade, Duncan astutely noticed:

The real conflict of interests, the true comparison, lies between the hand-worker and the power machine, and in proportion as real factory work increases, so will power machinists increase in number and the hand-workers decrease; and so will comparatively larger numbers of women and children at lower wages be employed, because of the many and minutely sub-divided processes which ensue. ${ }^{55}$

She concluded that 'the increase in occupation for women is chiefly found to be growing; firstly, in those industries which are their proper domain, and next in those trades in which power machinery is causing a redistribution of labour'. The introduction of machinery and new technologies was demanding new responsibilities of employers, many of whom were not taking these seriously. This was apparent in the case of accidents: 'The employer, then, has everything to gain and little to lose, except in cases of flagrant neglect, by the use of machinery; while the workman has little to gain, and stands to lose. ${ }^{56}$

54 Ibid.

55 'Report on the Working of the Factories and Shops Act', NSW Votes and Proceedings 4 (1904), 11.

56 Ibid., 12. 
Another issue Duncan investigated through her administrative role was that of child labour. Duncan investigated the case of children under fourteen years of age. Children regularly went on their own initiative to make an application at a factory. Parents were often 'easy-going' in their attitude towards children working in factories instead of attending school. Why were children so eager to work in the factories?

The point that came out prominently in the matter was the fact that the rejected children were all below par in some way, in health, education or discipline, and that they preferred the 'go' and excitement of factory life, with its comparative emancipation and the pride of wage-earning, to the individual mental effort of school life and its strict discipline. There was very little evidence that parents as a whole were anxious to curtail the period of school attendance, but a good deal of general 'slackness' was apparent. ${ }^{57}$

The issue of children workers was also discussed in the context of the employment of underaged children as fruit pickers. In the past, permission had been given for children between the ages of thirteen and fourteen, but those under thirteen had also slipped into the system. The danger Duncan identified was that

when tired of stoning fruit, [they would] slip away to an older friend or companion, and try their hand on some simple machine that looks easy to work and interesting to experiment upon, and when the factory is working at high pressure, foremen and forewomen are apt to lose sight of the small people. ${ }^{58}$

This was an inappropriate workplace for children:

In any case, a factory working at full pressure is no place for children, and the latest award, which raises their pay out of all proportion to their value, has now the desired effect of shutting them out from this particular occupation. Elderly women now do the work of fruit-picking, and their employers consider the results more satisfactory. ${ }^{59}$

The official appointment to factories of medical women was another area in which Duncan agitated. After an incident involving an injury to the hand of a young woman, Duncan believed there should be 'a medical woman officially appointed for work in the factories'. 'For the sake of themselves and of their offspring, our working girls have a right to the very best expert advice that can be brought to bear upon their working conditions.' In time, she argued,

57 'Report on the Working of the Factories and Shops Act', NSW Votes and Proceedings 2 (1909), 19.

58 'Report on the Working of the Factories and Shops Act', NSW Votes and Proceedings 5 (1914-15), 25.

59 Ibid. 
the public conscience will be roused to insist that the conditions of women's work shall in every avenue of public life be established on a basis better fitted to their own natural constitution, instead of being fitted into the gaps left in the pattern, and originally cut out for men. ${ }^{60}$

Duncan joined social reformers of the day who argued against the factory system in relation to healthy motherhood:

[I]t was much to be desired that this State should give its cordial and strong support to the principle of securing to women, the future mothers of Australian people, the unbroken rest which is so essential to prevent breakdown of bodily strength and nervous constitution ... For the working woman whose energies are by the nature of things devoted to the making of a hard living and to whom ... luxuries are forbidden, there remain broken health and lowered vitality, and all the other conditions which tell against happy and healthy motherhood. ${ }^{61}$

It was Duncan's pride in her professionalism as an administrator that she brought to the role that she emphasised when she finally left the position:

Whether from temperamental or physical causes, we all have our limitations, and I can only say that at least I have tried to do my duty conscientiously and without favour. It remains for those who are younger and more vigorous to carry on the work in the light of modern ideas and knowledge. ${ }^{62}$

Duncan's administrative reports illuminate the working conditions of women workers and more generally the condition of industrial workers at a time of dramatic social and industrial changes within the Australian workplace. These reports reflect an administrator implementing social change through her activities, which involved identifying and acting on improving the conditions of working-class women. Undertaking and performing these tasks represent a form of leadership, as they were influential acts advocating for and resulting in social and industrial change.

\section{Conclusion}

In this chapter I have argued that through an examination of the activities of three female factory inspectors the notion of women's administrative leadership can be explored historically. Duncan, Cuthbertson and Milne were all appointed

60 Ibid., 28.

61 'Report on the Working of the Factories and Shops Act', NSW Votes and Proceedings 19082 (2nd Session), 22.

62 'Report on the Working of the Factories and Shops Act', NSW Votes and Proceedings 1918 3, 20. 
to their jobs as factory inspectors at a time of rapid changes of industrialisation and urbanisation. The position came with considerable responsibility and direct influence, for administering the Factory Acts could have a major impact on highlighting and improving the conditions of working women. The three women discussed in this chapter administered the role in different ways, but all aimed to improve women's working conditions, which was not always a high priority within the male-dominated unions. Milne's approach could be characterised as one of a radical crusade to use the position to politicise working-class women. Cuthbertson was inspired by a feminist commitment to the improvement of women's position in society more generally. This was not a sentiment she shared with Duncan, who was not politically motivated but who believed her role was to administer the Acts as professionally as she could. For Duncan, it was the pioneering role she believed she was playing in paving the way for the independent career woman and making a distinctive contribution to women's place in society.

The history of female factory inspectors not only points to an example of women assuming positions of authority and responsibility. It also suggests ways that they exercised leadership by promoting an improvement of industrial conditions for women within a bureaucratic and administrative framework. In doing so, it argues for a more flexible and historically grounded understanding of leadership, which encompasses the opportunities available to women at a given time, the diversity of activities they undertook and the positions they adopted within their roles towards bringing about social change.

\section{References}

Anderson, Adelaide Mary. Woman in the Factory: An Administrative Adventure 1893-1921. London: John Murray, 1921.

Anderson, George. Fixation of Wages in Australia. Melbourne: Macmillan/ Melbourne University Press, 1929.

Banks, Olive. Faces of Feminism: A Study of Feminism as a Social Movement. Oxford: Martin Robertson, 1981-82.

Brennan, Deborah and Louise Chappell, eds. 'No Fit Place for Women?' Women in NSW Politics, 1856-2006. Sydney: UNSW Press, 2006.

Caine, Barbara. Victorian Feminists. Oxford: Oxford University Press, 1992-93.

Chin, Jean Lau, Bernice Lott and Janis Sanchez-Hucles. Women and Leadership: Transforming Visions and Diverse Voices. Oxford: Blackwell, 2007. 
'CIF to the Minister of Industry'. 7 January 1897, vol. 1. State Records of South Australia, Adelaide.

Daniels, Kay. 'Duncan, Annie Jane (1858-1943).' Australian Dictionary of Biography, Volume 8. Canberra: National Centre of Biography, The Australian National University, 1981.

Duncan, Annie. 'Woman's Place in the Industrial World.' The Public Service Journal 10 (November 1904): 13-14.

Finnimore, Christine. A Woman of Difference: Augusta Zadow and the 1894 Factories Act. Adelaide: Workcover, 1995.

Finnis, Jane. 'Louisa Twining and the Workhouse Visiting Society.' MA thesis, Department of History, University of Melbourne, 1995.

Frances, Raelene. 'Ord, Harrison(1862-1910).' Australian Dictionary of Biography. Volume 11. Canberra: National Centre of Biography, The Australian National University, 1988.

Frances, Raelene. The Politics of Work: Gender and Labour in Victoria, 1880 1939. Cambridge: Cambridge University Press, 1993.

Gillan, Helen E. A Brief History of the National Council of Women of Victoria, 1900-1945. Melbourne: NCW, 1944.

Grey, Madeline. Challenging Women: Towards Equality in the Parliament of Victoria. Melbourne: Australian Scholarly Publishing, 2009.

Grimshaw, Patricia. "The "Equals and Comrades of Men"? Tocsin and "the Woman Question".' In Debutante Nation: Feminism Contests the 1890s, edited by Susan Magarey, Sue Rowley and Susan Sheridan, 100-13. Sydney: Allen \& Unwin, 1993.

Gurney Fry, Elizabeth. Observations on the Visiting, Superintendence, and Government of Female Prisoners. London: J and A. Arch, 1827.

Hacking, Ian. 'Making Up People.' In Reconstructing Individualism: Autonomy, Individuality, and the Self in Western Thought, edited by T. C. Heller, M. Sosna and D. E. Wellbery, 222-36. Stanford: Stanford University Press, 1986.

Hacking, Ian. 'How Should We Do the History of Statistics?' In The Foucault Effect, edited by G. Burchett, C. Gordon and P. Miller, 181-195. Chicago: Chicago University Press, 1991. 
Harrison, Barbara and Melanie Nolan. 'Reflections in Colonial Glass? Women Factory Inspectors in Britain and New Zealand 1893-1921.' Women's History Review 13(2) (2004): 263-88.

Jones, Helen. In Her Own Name: A History of Women in South Australia from 1836. Adelaide: Wakefield Press, 1986.

Kellerman, Barbara and Deborah L. Rhode, eds. Women and Leadership: The State of Play and Strategies for Change. San Francisco: Wiley, 2007.

Livesey, Ruth. 'The Politics of Work: Feminism, Professionalisation and Women Inspectors of Factories and Workshops.' Women's History Review 13(2) (2004): 233-62.

McGowan, Henrietta C. and Margaret Cuthbertson. Woman's Work. Melbourne: Thomas C. Lothian, 1913.

Macintyre, Stuart. Winners and Losers: The Pursuit of Social Justice in Australian History. Sydney: Allen \& Unwin, 1985.

Milne, Agnes. 'Working of the Factory Act.' Journal of Agriculture and Industry ii(4) (November 1898): 386-7.

Milne, Agnes. 'Woman's Work and Wages.' Journal of Agriculture and Industry iii(3) (October 1899): 342-3.

Norris, Ada. Champions of the Impossible: A History of the National Council of Women of Victoria 1902-1977. Melbourne: The Hawthorn Press, 1978.

Ord, Harrison. 'Chief Inspector of Factories, to Under Secretary.' 24 January 1894, VPRS 3992, Unit 787, Item X 94/5122. Public Records Office, Melbourne.

Prest, Wilfrid, Kerrie Round and Carol Fort, eds. The Wakefield Companion to South Australian History. Adelaide: Wakefield Press, 2001.

'Report of the Chief Inspector of Factories, Work-Rooms and Shops.' Victorian Parliamentary Papers, 1896-1910.

'Reports of Inspectors of Factories.' Proceedings of the Parliament South Australia 2 (54) (1897).

'Report on the Working of the Factories and Shops Act.' NSW Votes and Proceedings 3 (1903); 4 (1904); 2 (2 ${ }^{\text {nd }}$ Session) (1908); 5 (1914-15); 3 (1918).

Rhodes, Gerald. Inspectorates in British Government: Law Enforcement and Standards of Efficiency. London: Allen \& Unwin, 1981. 
Russell, Penny. 'A Wish of Distinction': Colonial Gentility and Femininity. Melbourne: Melbourne University Press, 1994.

Sawer, Marian and Gail Radford. Making Women Count: A History of the Women's Electoral Lobby in Australia. Sydney: UNSW Press, 2009.

Smith, Dayle. Women at Work: Leadership for the Next Century. New Jersey: Prentice Hall, 2000.

Taylor, Arthur J. Laissez-Faire and State Intervention in Nineteenth-Century Britain. London: Macmillan, 1972.

Uhl-Bien, Mary, Russ Marion and Bill McKelvey. 'Complexity Leadership Theory: Shifting Leadership from the Industrial Age to the Knowledge Era.' In Leadership, Gender, and Organisation: Issues in Business Ethics, edited by P. H. Werhane and M. Painter-Moralnd, 128-31. London: Springer, 2011.

Victorian Government Gazette, 3rd Supplement (13) (1920).

Walkowitz, Judith R. City of Dreadful Delight: Narratives of Sexual Danger in Late-Victorian London. London: Virago, 1992.

Woman's Sphere, 10 May 1903. 
This text taken from Diversity in Leadership: Australian women, past and present, edited by Joy Damousi, Kim Rubenstein and Mary Tomsic, published 2014 by ANU Press, The Australian National University, Canberra, Australia. 